\title{
A Review of Cracking Behavior and Mechanism in Clayey Soils Related to Desiccation
}

\author{
Xin Wei $(\mathbb{D}$, Chongyang Gao, and Ke Liu \\ Department of Civil Engineering, School of Human Settlements and Civil Engineering, Xi'an Jiaotong University, \\ Xi'an 710049, China \\ Correspondence should be addressed to Xin Wei; weixin_star@126.com
}

Received 17 March 2020; Revised 30 July 2020; Accepted 4 August 2020; Published 14 August 2020

Academic Editor: Daniele Baraldi

Copyright $\odot 2020$ Xin Wei et al. This is an open access article distributed under the Creative Commons Attribution License, which permits unrestricted use, distribution, and reproduction in any medium, provided the original work is properly cited.

Cracks in clayey soils are common during desiccation. The presence of cracks significantly alters the mechanical and hydraulic properties of soils. The objective of this article is to summarize the works on cracking behavior and mechanism in clayey soils related to desiccation. Historical field investigations, laboratory experimentations, identified mechanisms, and numerical approaches for modeling the process of cracking during desiccation are discussed. The experimental approaches for interpreting the mechanisms of cracking are systematically summarized and comprehensively reviewed based on the in situ observations and laboratory experimentations from the literature. The soil mechanics-based approaches resumed in this article according to the fracture mechanics theory and numerical results highlight the cracking development mechanism. Concerning the plasticity characteristics of clayey soils, researches on soil fracture mechanics should be paid more attention. More in situ experimentations and numerical researches are suggested for future researches to better understand the cracking behavior and mechanism in clayey soils related to desiccation.

\section{Introduction}

It is commonly recognized that cracks form in clayey soils during desiccation when the tensile stress caused by suction is larger than the tensile strength of soil. Cracks can greatly weaken the engineering properties of clayey soils in various applications, such as geotechnical, water conservancy, and environmental engineering [1-7]. In many conditions, there is direct inducement of damage for many soil-based structures. Cracks can affect soil's hydromechanical properties such as strength, bearing capacity, permeability, and compressibility. The overall stability of Earth structures and foundations (slopes, buildings, dams, and embankments) can also be influenced by the consequences of cracks. In addition, cracks can create preferential path for water in slopes, which greatly influence the transport rate and velocity of moisture, solutes, and microorganisms in soil profile, and affect the crops growth and production. The functions of clay soil barrier such as landfill liners, top covers, and buffer/sealing/backfilling materials for waste storage can be weakened by the appearance of cracks. Finally, cracks can also accelerate the weathering damage and erosion in historic sites. In engineering works, the desiccation cracks in clayey soils have been widely reported since the twentieth century [8-14].

Because of influences of environmental conditions and representativeness of sampling, the in situ observations are rather important compared with laboratory experiments. Desiccation cracks in clayey soils have been observed in situ by many researchers $[5,9,10,15-18]$, where the characteristics of cracks, such as depth, area, width, and crack ratio, under the drying environments were analyzed. Laboratory experimentations have mainly concentrated on the behaviors of clayey soil when specimens are dried from a saturated state $[6,7,19-27]$. Indeed, there are many factors that influence crack formation and propagation such as drying conditions (temperature, relative humidity, etc.), specimen dimensions, boundary conditions, and soil properties. However, at present, the experimental analysis is mainly qualitative. There is a lack of quantitative analysis. 
Soil mechanics for explaining the cracking behavior and mechanism have been employed. Tensile forces set up by shrinkage are larger than the tensile strength of the soil when cracks occur. In other cases, such as nonuniform drying, complex patterns of cracks are set up when the shear stress exceeds the shear strength of soils. Tensile strength and tensile stresses are two main factors involved in cracking, the former of which has received more attention. Technologies for measuring the tensile strength of clayey soils have been developed by many researchers [28-30]. Researches concerned tensile stresses caused by desiccation have been carried out with clayey soils drying from slurry state $[19,28]$. Fracture mechanics was applied to analyze the formation and evolution of cracks in clayey soils [25]. It is one of the main tools to study the destruction of soil cracking. There are two ways (stress and energy) to explain the process of fracture development by using fracture mechanics. The involved fracture mechanics parameters are stress intensity, fracture toughness, and energy release rate. There are strong evidences for judging whether the soil cracks and when it cracks [31]. Besides, digital image correlation method is useful for interpreting cracking mechanisms such as initiation, propagation, bifurcation, and coalescence of cracks $[25,32]$.

In addition, various models have been presented for modeling the cracking behavior [12, 21, 33-39]. With these numerical methods, cracking behaviors such as the formation and propagation of cracks have been researched. Some of numerical modelings of cracks are on the basis of the finite element method (FEM). Otherwise, it is complicated to model cracking process with a continuum-based FEM method. As an alternative, the discrete element method (DEM) is an appropriate method with its capability of demonstrating the discrete characteristics of soil particles. The other theories and models such as linear elastic fracture mechanics (LEFM) and distinct lattice spring model (DLSM) [40] are introduced. Since soil is a complicated geomaterial, the cracking behavior related to desiccation is influenced by a large amount of internal and external factors. Therefore, it is difficult to suggest an ideal model to simulate the complicated cracking process with just a number of parameters. The mechanism of cracks related to desiccation is still not well comprehended; in particular, the prediction of cracks also faces great challenges.

Although cracks in soils have been a major problem in a number of applications and an orientation of research, their development compared with the capability of modeling soil failure as a continuum is still limited. This paper presents a review of the literature to achieve a clear and systematical understanding of the cracking behavior and mechanism in clayey soils related to desiccation. The comprehensive summary can be valuable for solving problems associated with clayey soils and for presenting more efficient approaches in the future.

\section{Experiments and Mechanism for Interpreting Cracking Behavior}

Researches have been performed on desiccation cracks since the beginning of the twentieth century. The investigation of cracks due to desiccation in geological applications also traces back to the same time. Kindle [8] and Longwell [9] are the earliest researchers on this domain. In previous researches, a large amount of the works in geoengineering was principally qualitative and descriptive. Nowadays, the quantitative behaviors, mechanism of crack formation, and numerical researches have been paid more attention.

2.1. Experiments. Several studies have been performed with the purpose of giving a better understanding of the characteristics on the morphology of the cracks related to desiccation. Different techniques have been used in order to quantify the cracking behaviors in soils. For example, to measure the cracks directly with a rule is one of the methods $[41,42]$. However, it is not easy to quantify the cracks with irregular form and complicated geometry. For the purpose of better analyzing the characteristics of cracks, digital imaging methods have been applied to quantify the parameters of microcracks $[29,30,43]$. Digital image correlation (DIC) has become an efficient method, which can better quantitatively analyze the variation of cracking parameters during desiccation. The analytical stages of performing digital image correlation are as follows: (1) taking the images of cracks from the beginning of desiccation until the cracks are well developed (at the end of desiccation), (2) comparing the deformed image with the reference image and calculating the evolution of displacements and strains in the chosen zines in which cracks developed, and (3) detailed analysis of the displacement and strains in the vicinities of identified cracks. Table 1 summarizes main types of experimental work of cracking test during desiccation.

In addition, for better understanding the relationship between physical properties of soil materials and macroscopic cracking behavior, mesostructural and microscopic researches have been increasingly carried out. The properties of clayey particles at microscopic scale and the application of experimental technique at grains or aggregates scale which is less than $100 \mu \mathrm{m}$ are frequently analyzed. Thus, the arrangement and distribution of pores, particles, and assemblies are determined, including their cohesion and contact patterns. Many advanced techniques and methods are also developed, for example, scanning electronic microscope (SEM), X-ray diffraction, mercury intrusion porosimetry (MIP), and transmission electron microscope (TEM). These are efficient and significant for identifying the microstructures of clays and their mechanical characteristics. Generally, four parameters are analyzed microscopically: structure or fabric, arrangement, surface area, and binding capacity of clay particles.

\subsection{The Morphological Characteristics of Cracks. Desiccation} cracks have been observed in situ and in laboratory, respectively. Desiccation cracks are characterized in different clayey soils, for example, different layers of lacustrine clays, desiccated hydraulic fills, silty sand, and moderately to highly plastic clayey soil. Parameters such as crack patterns, orientations, and depths of the cracks are analyzed [9]. In Queensland, Australia, the effects of desiccation on the tailing ponds were interpreted [15]. The factors that affect 
TABLE 1: Resume of reviewed experimental works on desiccation cracks in soils.

\begin{tabular}{|c|c|c|c|c|}
\hline Test type & Reference & Material & Investigated parameters & $\begin{array}{l}\text { Digital } \\
\text { imaging } \\
\text { method }\end{array}$ \\
\hline \multirow{8}{*}{ Rectangular tests } & $\begin{array}{l}\text { Corte and Higashi } \\
{[19]}\end{array}$ & Bloomington soil & $\begin{array}{l}\text { Desiccation experiments with different support } \\
\text { materials, densities, thicknesses of soil samples, } \\
\text { and influences of gravel inclusions }\end{array}$ & \\
\hline & Lau [20] & $\begin{array}{l}\text { Indian Head till and } \\
\text { Regina clay }\end{array}$ & $\begin{array}{l}\text { Crack spacing, soil suction, shrinkage strain and } \\
\text { predicted crack depth }\end{array}$ & \\
\hline & Miller et al. [44] & Landfill clays & $\begin{array}{c}\text { Under drying-wetting cycles, the influence of crack } \\
\text { intensity }\end{array}$ & \\
\hline & Yesiller et al. [45] & Three compacted clays & $\begin{array}{l}\text { Under drying-wetting cycles, the effect of crack } \\
\text { intensity }\end{array}$ & \\
\hline & Lakshmikantha et al. & Silty clay & Specimen dimensions, crack ratio & \\
\hline & Wei et al. [25] & $\begin{array}{l}\text { Two mixtures of kaolinite } \\
\text { and montmorillonite }\end{array}$ & $\begin{array}{c}\text { Drying tests with different supports, local strains and } \\
\text { displacements }\end{array}$ & $\checkmark$ \\
\hline & Zhang. et al. [26] & Block clays & Influence of $\mathrm{NaCl}$ content on desiccation & $\checkmark$ \\
\hline & Cordero et al. [47] & 11 sand-kaolinite mixtures & $\begin{array}{c}\text { The onset of crack initiation and the subsequent } \\
\text { evolution in horizontal strains }\end{array}$ & $\checkmark$ \\
\hline \multirow{7}{*}{ Circular tests } & Kindle [8] & Mud & $\begin{array}{c}\text { Drying rate, influence of salinity, effect of structure of } \\
\text { mud on cracks behavior }\end{array}$ & \\
\hline & $\begin{array}{l}\text { Groisman and } \\
\text { Kaplan [48] }\end{array}$ & Coffee-water mixtures & Influence of layer thickness and boundary limitations & \\
\hline & $\begin{array}{l}\text { Toramaru and } \\
\text { Matsumoto [49] }\end{array}$ & Starch-water mixture & Drying rate, cracking joint formation & \\
\hline & Tang et al. [6] & Xiashu clayey soil & $\begin{array}{c}\text { Water evaporation rate, volumetric shrinkage, crack } \\
\text { evolution }\end{array}$ & $\checkmark$ \\
\hline & Costa et al. [50] & Starch/clay/fine sand & $\begin{array}{l}\text { Thickness of samples, desiccation rate, crack } \\
\text { formation, flaw distribution, and fracture energy }\end{array}$ & \\
\hline & Li et al. [24] & Residual clayey soil & Effect of vegetation roots on the preferential flow & $\checkmark$ \\
\hline & Wang et al. [14] & Clayey soil & Evolution of crack patterns and surface strain analysis & $\checkmark$ \\
\hline \multirow{3}{*}{ Long mould tests } & $\begin{array}{l}\text { Nahlawi and } \\
\text { Kodikara [51] }\end{array}$ & Werribee clay & $\begin{array}{l}\text { Variation of water content, development of crack } \\
\text { patterns, drying rate, crack spacing, and depth }\end{array}$ & \\
\hline & Péron $[21]$ & Bioley silt and rock powder & Shrinkage strain, soil-water characteristics & \\
\hline & Tang [23] & $\begin{array}{l}\text { Clayey soils of low } \\
\text { plasticity }\end{array}$ & $\begin{array}{c}\text { Evolution of cracks and desiccation cracking } \\
\text { mechanism }\end{array}$ & \\
\hline \multirow{4}{*}{$\begin{array}{l}\text { Field experiments } \\
\text { of clay cracking }\end{array}$} & Longwell [9] & Lacustrine clay & $\begin{array}{c}\text { Mud curling phenomenon, different types of crack } \\
\text { patterns }\end{array}$ & \\
\hline & Kong [16] & Clayey soil in Chengdu & Morphology of cracks & \\
\hline & Konard and Ayad & Saint Alban clay & Cracking patterns in soft clay & \\
\hline & Philip et al. [52] & Saint Alban clay & Field tests on landfill liners & \\
\hline
\end{tabular}

the formation and morphology of cracks in soils are reviewed. In northwestern China, there is large-scale distribution of clayey loess. Hierarchical pattern formation in clayey soils can be observed in situ. It is concluded that the crack patterns are not formed simultaneously. Otherwise, they formed in a sequential and hierarchical way. The previous soil blocks are tessellated by new cracks and divided into smaller cells (see Figure 1). The scale of cracks can also be influenced by inhomogeneous water content. With larger water content, the cells tend to be bigger. Orthogonal patterns and nonorthogonal patterns of cracks can be observed obviously (see Figure 2).

The crack patterns tend to be orthogonal or nonorthogonal. In a homogeneous soil matrix, a crack will develop perpendicularly to the direction of maximum stress. Any subsequent crack tends to propagate to reach the

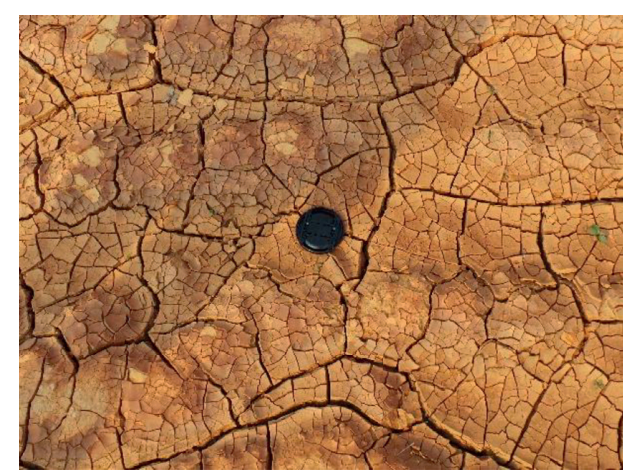

Figure 1: Hierarchical pattern formation in clayey loess related to desiccation (observation in situ, Jingyang, Shaanxi Province, China). 


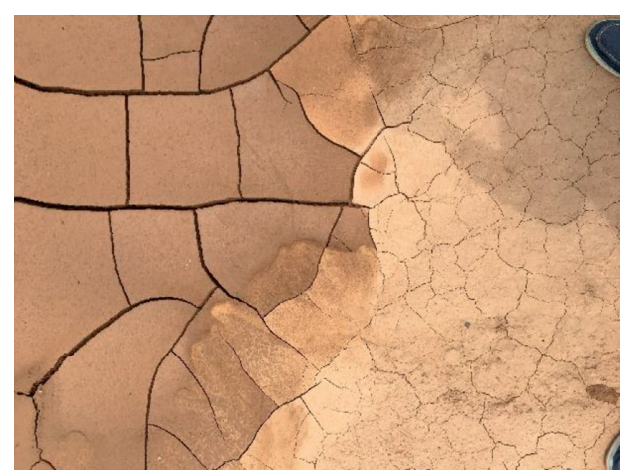

Figure 2: Different scale of cracking patterns in clayey loess related to desiccation (observation in situ, Xi'an, Shaanxi Province, China).

preexisting crack perpendicularly because the stress in the vicinity of an existing crack is parallel to its developing direction. The cracks do not connect perpendicularly due to the effect of vicinity cracks on the local stress field with nonorthogonal patterns, such as hexagonal patterns $[25,53,54]$. As proposed by Bazant and Cedolin [53], cracks initiate simultaneously and meet each other to form a crack network. Figure 3 shows the parallel cracks that are considered to be two-dimensional.

Most of physical observations are consisted in geological papers, and measurable parameters that control soil cracking are not investigated. Analyses of quantitative relationship between crack spacing and these physical factors are still insufficient.

Recently, 3D analysis of cracking propagation has also drawn many attentions. There are several methods to determine the vertical displacement. The first method is to correlate digital images with software, for example, VIC-3D [25], which allows measuring the vertical displacement directly. Another solution to determine the vertical displacements is to measure them with a laser [55], a Vernier caliper [56], or other devices.

2.3. Measuring Tensile Strength of Soils. Compared with compression or shear strength, the tensile strength of soils is generally weaker. The relationships between stress and strain of the soils during tensional test are very important for understating cracks in soils. There are various factors that influence the tensile strength of soils, for example, mineralogy, grain size distributions, and porosity. Besides, structure of soil mass, which means the arrangement of particles, also affects the tensile strength. It has been recognized that it is necessary to understand the tensile strength and its relation to water content and degree of saturation during desiccation process of a soil.

A number of researches have been carried out on the tensile characteristics of clayey soils. It is assumed that cracking in soils is a result of performance of tensile stresses. Generally, the tensile strength can be determined with indirect and direct methods, respectively. The methods with determining the relationship between tensile strength and the other mechanical parameters are indirect. Brazilian tensile test, bending tests, and axial fracturing test are most commonly used indirect methods. The direct methods are depending on applying tensile forces or loads directly on samples. Commonly, the axial and uniaxial tensile tests are performed with tensile forces and strains recorded at the same time. Drained tension tests on London clay were conducted by Bishop and Garga [57]. The results show that the tensile strength of remolded London clay is close to zero. The maximum tensile stress was measured in the indirect (Brazilian) test [58]. Two types of tests, beam flexion and direct tension tests, are performed on two clays in the research of Ajaz and Parry [59]. The measurements of tensile strength of various clays at different scales were carried out by Avila [28], with double triangular-shaped specimens. The tensile strength of a soil during drying was measured in the research of Villar et al. [60]. Its correlations with total and matric suctions were also analyzed. A direct tensile test device was developed by Tang et al. [29] in order to identify the tensile strength of compacted clayey soil with different initial state. It is demonstrated that water content is an important factor that influences the tensile strength of compacted soil.

Compared with indirect tensile tests, the direct tensile tests are difficult to realize because of sample preparation and fixing during the tensile tests. Therefore, improvement of experimental devices and methods is significant for determining tensile strength for direct tests. Generally, it is concluded that the tensile stress-at-failure increased with increasing of water content. In addition, tensile stresses vary with various factors, such as the test type, loading rates, and definition of failure.

\section{Mechanism}

The governing mechanisms of desiccation are analyzed based on the experiments performed above (some listed in Table 1). As stated before, the desiccation cracks form when the tensile stress develops in soils due to the fact that restrained shrinkage exceeds the tensile strength. The shrinkage can be considered to be free from cracks if the drying soil is free of any restraints, which corresponds with drying environmental and soil properties.

3.1. Volumetric Shrinkage and Cracking Formation Process. Soil shrinkage is in response with the stress state. The initiation and propagation of cracks correspond tightly with volumetric shrinkage of soils. Clayey soils shrink mainly due to the hydrophilic clay minerals. During drying, water evaporates from the surface in a fully saturated homogeneous clayey soil. In the beginning of desiccation, the superficial water evaporates first and the stress-strain states are not influenced. A water-air meniscus between clay particles formed when the water-air interface gradually reached the clay surface. Thus, the capillary suction appears in the upper layer of soil sample. With the evaporation of water, the capillary suctions among the clay particles increase. At the same time, the curvature of capillary meniscus increases. Thence the clay shrinks and consolidates. From the microscale aspect, it can be imagined that each of soil grains on 

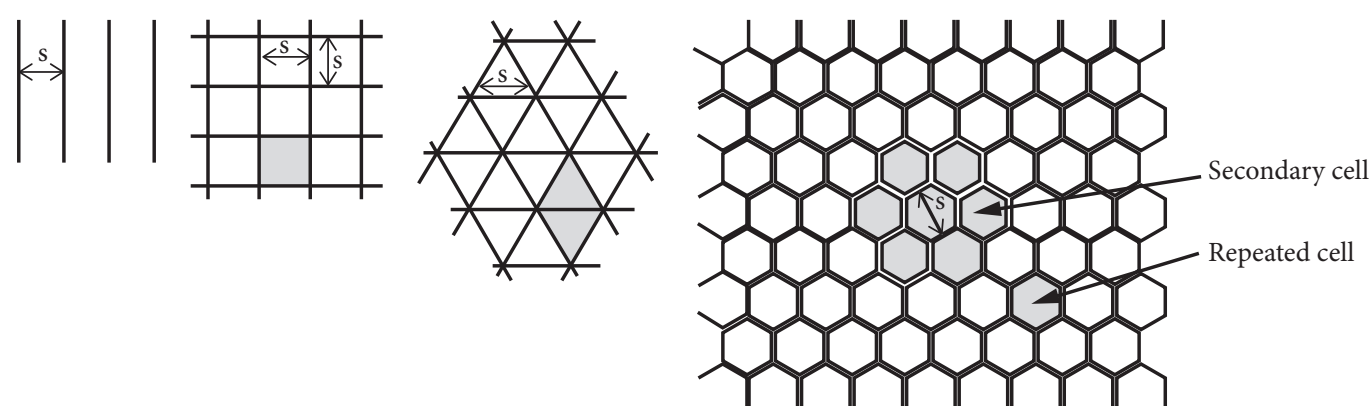

After bifurcation

= Open crack

- Closed crack
(a)
(b)
(c)
(d)

Figure 3: Theoretically plausible patterns of desiccation cracks in idealized media [53].

the layer surface is controlled by tensile force, which is due to the increase of capillary suction from the nearby particles. A tensile stress field is therefore developed in the upper layer. As soon as the tensile stress is larger than the tensile strength of soils, cracks appear on the surface (see Figure 4) [6]. At the microscopic scale, the clayey particles are reorganized and are closer to each other, with decreasing void ratio. At the macroscopic scale, this phenomenon is presented by volumetric shrinkage, which can be demonstrated by void ratiowater content curve.

Soil shrinks with the increase of soil plasticity. For example, for the same content of clay minerals in a soil, compared with kaolinites, montmorillonite suffers a greater volume of change during drying and wetting. It is expected that, for two samples from a given material which are with the same initial water content and different soil fabrics, the one with dispersed structure shrinks most.

Other parameters that affect shrinkage of clays are also investigated by researchers. It is identified that the amount of sand reduces the drying shrinkage in soils. The strains caused by shrinkage were initially proportionate to water content and did not rely on dry density of soil samples in these researches [61-63]. Besides, the dielectric constant of the pore fluid is also one factor, which influences shrinkage of soils.

3.2. Failure Criterion of Soils under Tension. Cracks can be predicted with the choice of a failure criterion with the estimation of the stresses or strains in a soil. According to the research of Newmark [64], failure is defined at the beginning of loss of shearing resistance in cohesive soils. Mohr-Coulomb theory can be considered to be one of the most widely known failure criteria, which is shown in Figure 5. The shear strength of a soil which locates at a point on a particular plan with regard to the effective stresses can be illustrated linearly to the normal stress.

$$
\tau_{f}=c^{\prime}+\sigma_{n}^{\prime} \tan \phi^{\prime},
$$

where $\tau_{f}$ represents shear strength, $c^{\prime}$ represents effective cohesion intercept, $\sigma_{n}^{\prime}$ is normal stress, and $\phi^{\prime}$ is effective friction angle.
The relationship between the effective principal stresses at failure and the shear strength can be expressed using the following equations (see Figure 5):

$$
\begin{aligned}
\sin \phi^{\prime} & =\frac{\left(\sigma_{1}^{\prime}-\sigma_{3}^{\prime}\right) / 2}{c^{\prime} \cot \phi^{\prime}+\left(\sigma_{1}^{\prime}+\sigma_{3}^{\prime}\right) / 2}, \\
\left(\sigma_{1}^{\prime}-\sigma_{3}^{\prime}\right) & =2 c^{\prime} \cos \phi^{\prime}+\left(\sigma_{1}^{\prime}+\sigma_{3}^{\prime}\right) \sin \phi^{\prime},
\end{aligned}
$$

where $\sigma_{1}^{\prime}, \sigma_{3}^{\prime}$ represent effective principal stresses, respectively.

Equation (3) refers to the Mohr-Coulomb failure criterion, which can be predicted as a ratio of unconfined compressive strength $Q_{u}$ to tensile strength $\sigma_{t}$. It changes on the basis of the frictional properties of the material:

$$
\frac{Q_{u}}{\sigma_{t}}=\frac{2 \sin \phi^{\prime}}{1-\sin \phi^{\prime}}
$$

The Mohr-Coulomb failure criterion is applied widely in geotechnical engineering for the purpose of quantifying the soil behavior under compressions. However, there is still some limitation for interpreting the behavior of soil in tension as the yield conditions in the tensile stress filed are mostly nonlinear $[65,66]$. Besides, there are other failure criteria such as Mohr-Paul, Griffith, Griffith-Brace, and Modified Mohr-Coulomb theories [67-69]. All these criteria can describe the soil behavior under tensile forces. However, for Modified Griffith theory or the Modified Mohr-Coulomb failure criteria, there are some limitations caused by the lack of experimental information to define the nonlinear part of the failure criterion [1].

3.3. Fracture Mechanics and Desiccation Cracking of Soils. The fracture mechanics were firstly established in the 60s. However, the elementary concept of crack evolution was developed by Griffith in 1921. The crack is considered to propagate when the energy released upon a growing crack is not enough to provide all the energy required for the development of crack $[70,71]$. Considering a crack, which is shown in Figure 6, it is in a nonhomogeneous tensile stress 


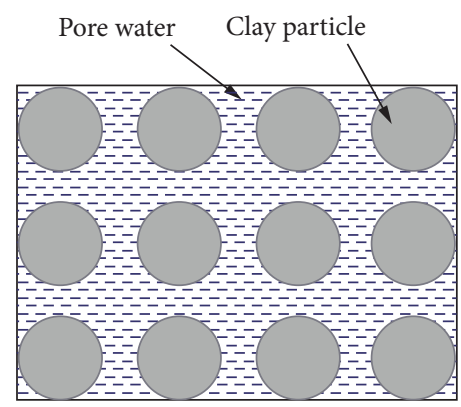

(a)

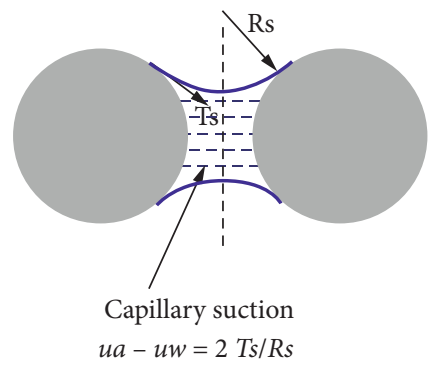

(c)

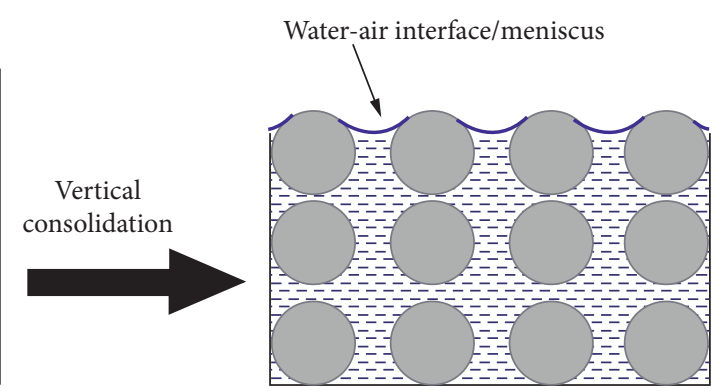

(b)
Tensile stress developed in

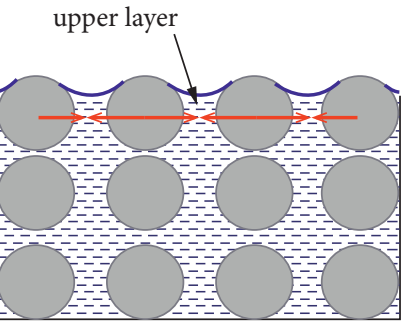

(d)

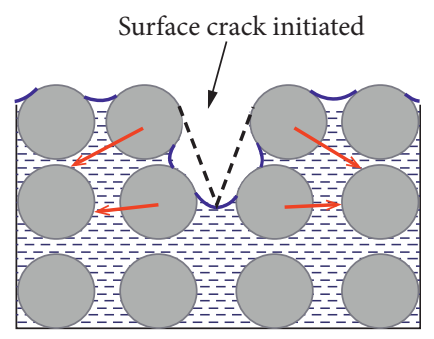

(e)

FIgURE 4: Schematic drawing of soil crack initiation process. (a) Initial fully saturated soil; (b) water-air interface meniscus developed between soil particles; (c) capillary suction between soil particles; (d) tensile stress developed in the upper layer; and (e) surface crack initiated [6].

field. If there are effects of external forces when the crack propagates by a certain distance $\delta$, then the following equations can be obtained:

$$
\begin{gathered}
\frac{\delta U}{\delta a}=\frac{\delta W}{\delta a}, \\
\frac{\delta U}{\delta a}=G, \\
\frac{\delta W}{\delta a}=R,
\end{gathered}
$$

where $U$ represents elastic energy release, $W$ represents energy required for crack growth, $R$ is the crack resistance, and $G$ is the elastic energy release rate per crack tip or also is called "crack driving force".

At the crack tip, the characteristics of an elastic stress distribution have been analyzed. Equation (8) expresses the stress and displacement distributions in the predominant terms [72]. $K_{1}$, called the stress intensity factor, depends on cracking modes, aspect, and dimensions of cracks. In threedimensional researches, three modes of cracks are presented, respectively (see Figure 7). In each condition, the local stress distribution corresponds with those given in Equation (8).

Equation (6) expresses the energy condition in which $G$ has to reach the value of $R$ before the occurrence of crack initiation. $G$ has to reach a certain critical value $G_{i c}$ if $R$ is a constant. Correspondently, the stress intensity factor $K$ has to exceed a critical value $K_{i c}$, which refers to "fracture toughness."

$$
\begin{aligned}
\sigma_{x} & =\frac{K_{1}}{\sqrt{2 \pi r}} \cos \frac{\theta}{2}\left(1-\sin \frac{\theta}{2} \sin \frac{3 \theta}{2}\right), \\
\sigma_{y} & =\frac{K_{1}}{\sqrt{2 \pi r}} \cos \frac{\theta}{2}\left(1+\sin \frac{\theta}{2} \sin \frac{3 \theta}{2}\right), \\
\tau_{x y} & =\frac{K_{1}}{\sqrt{2 \pi r}}\left(\sin \frac{\theta}{2} \cos \frac{\theta}{2} \cos \frac{3 \theta}{2}\right), \\
u & =\frac{K_{1}}{4 G} \sqrt{\frac{r}{2 \pi}}\left[(2 \kappa-1) \cos \frac{\theta}{2}-\cos \frac{3 \theta}{2}\right], \\
v & =\frac{K_{1}}{4 G} \sqrt{\frac{r}{2 \pi}}\left[(2 \kappa+1) \sin \frac{\theta}{2}-\sin \frac{3 \theta}{2}\right],
\end{aligned}
$$

where $\kappa=(3-4 \nu)$ for plane strain and $\kappa=(3-v) /(1+\nu)$ for plane stress.

In the researches of fracture mechanics, desiccation cracking is regarded as a mechanical process. Fracture mechanics is regarded to be one of the main tools to study soil cracking. There are two ways, stress and energy, respectively, to explain the process of fracture development by using fracture mechanics. The involved fracture mechanics parameters are stress intensity factor, fracture toughness, and energy release rate. There are strong lines of evidence for judging whether the soil cracks and when it cracks. The failure (cracking) criterion is on the basis of the critical stress field. Otherwise, it is considered that cracks during desiccation are totally different from the mechanical cracking due 


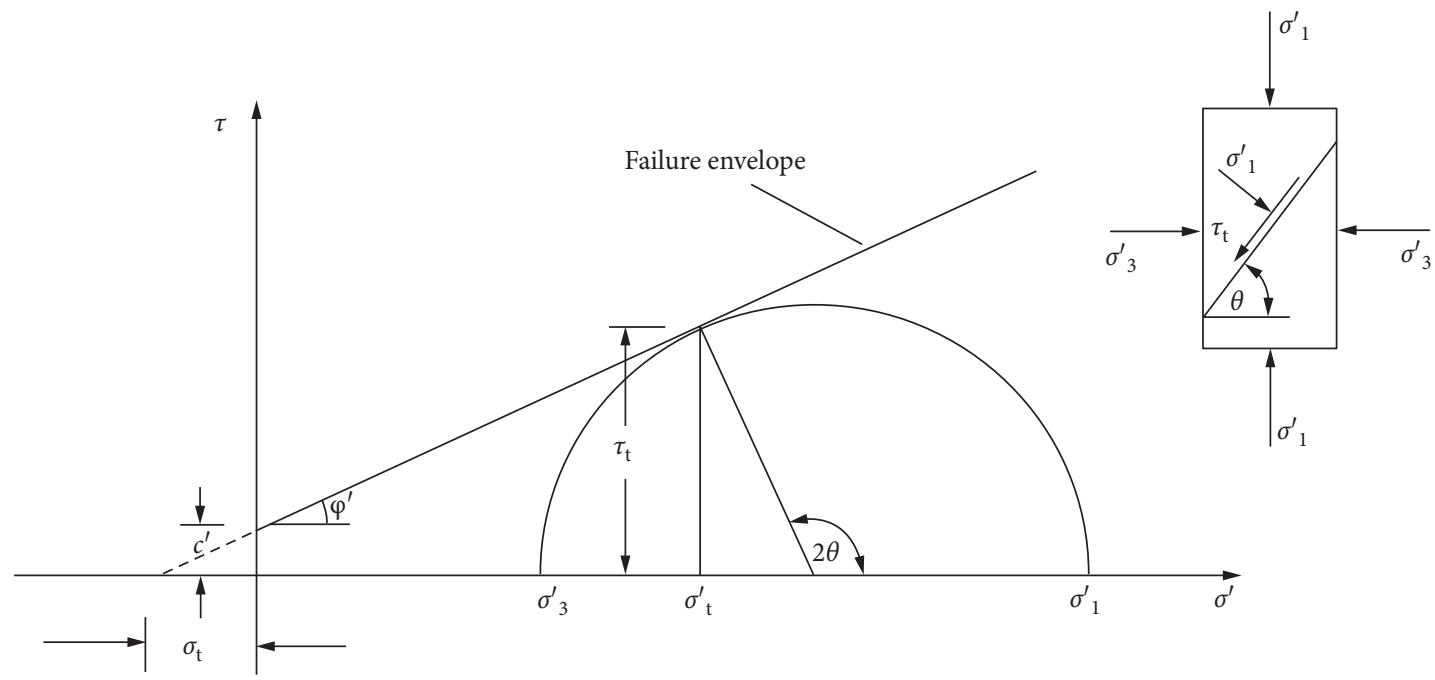

FIgURE 5: Mohr-Coulomb failure criterion.

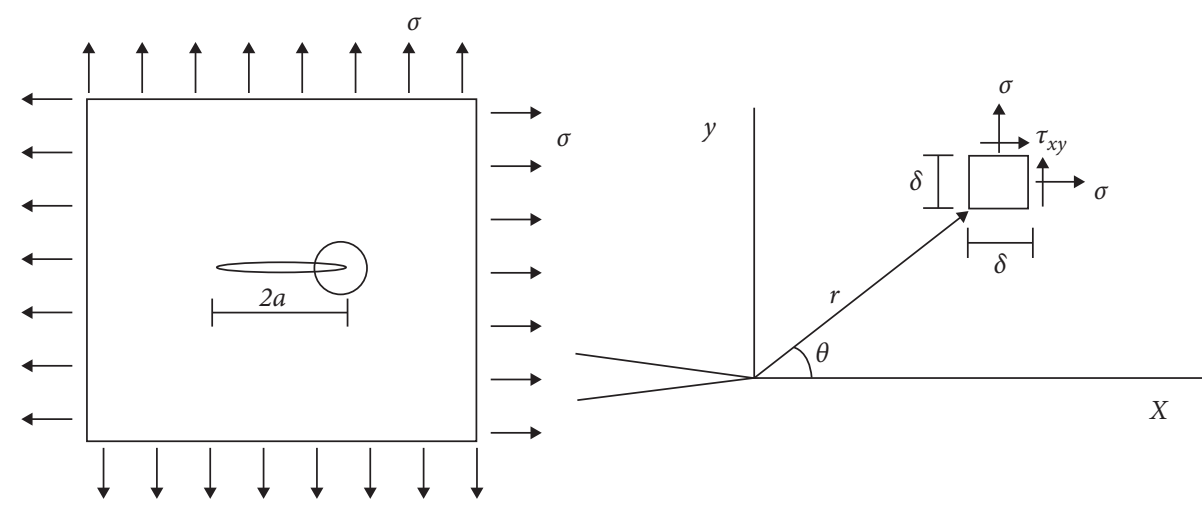

FIGURE 6: Crack in a finite plate.

to lose of material mass [19]. Moreover, the mechanism of initiation of cracks is still not addressed in fracture mechanics because it only explains the propagation of cracks. On the basis of the above discussions, the fracture mechanics is still not adequate dealing with the problem of cracks in soils related to desiccation.

3.4. Analysis of Cracks in Clayey Soils with Numerical Modeling Methods. To overcome the shortcomings of experiments, for several decades, theoretical and numerical researches for modeling the cracks in clays related to desiccation have been carried out for interpreting the cracking mechanisms. With numerical methods, the cracking process has been analyzed on the basis of finite elements method (FEM) [73-78] and discrete element method (DEM) $[39,79,80]$. In addition to the laboratory testing, the predictions of cracks due to desiccation in clays and the intrinsic mechanism are still inadequate. The reviewed numerical works on desiccation cracks in soils are summarized in Table 2.

Desiccation cracking has been analyzed with FEM method in various researches [75, 88, 89]. A model called
Mohr-Coulomb model is used to describe the compressiveshear behavior of soils with the identifications of friction angle and cohesion, which are constant during modeling. In addition, many studies have concluded that, for clayey soils, a mix-mode cohesive fracture model can be applied to obtain the multifracturing and cycle loading-unloading behavior of soil particles. However, the propagation of cracks which includes discontinuity in the soil matrix was not taken into account. Thus, cohesive fracture and interface elements are often recommended in FEM code in order to model the cracking process during drying. For example, a PDS-FEM model was developed by Hirobe and Oguni [78]. With this model, any fracture criterion can be implemented, such as Griffith's energy criterion and the tensile strength criterion (see Figure 8). The seamless analysis of the drying-induced strains and fracture of grain continuum can be performed. One crack or multiple cracks, as flaws, are usually preset in a continuous soil medium in the application of FEM method [75]. The boundary of model can also be considered to be a crack [73], which decreases the efforts to predict the cracking process. A hydromechanical model was developed by Vo et al. [86] on the purpose of simulating the desiccation cracking in clayey soils with a cohesive fracture method. In 


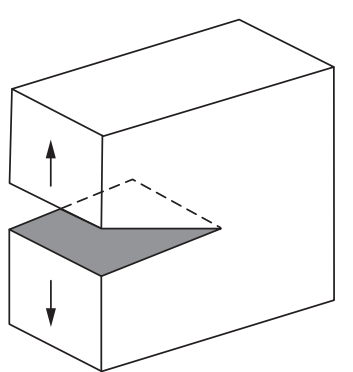

(a)

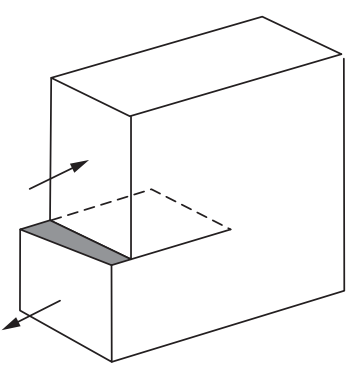

(b)

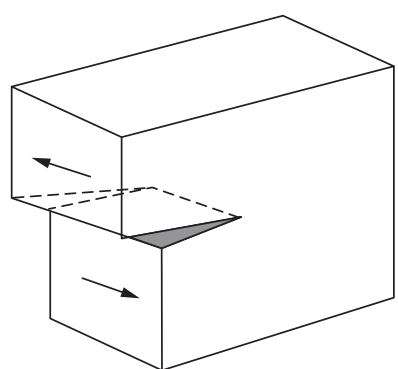

(c)

Figure 7: The three modes of cracking [25]. (a) Mode I opening mode. (b) Mode II sliding mode. (c) Mode III tearing mode.

TABLE 2: Resume of reviewed numerical works on desiccation cracks in soils.

\begin{tabular}{|c|c|c|c|}
\hline & Approaches & Reference & Descriptions \\
\hline \multirow{6}{*}{$\begin{array}{l}\text { Systems } \\
\text { approaches }\end{array}$} & $\begin{array}{l}\text { FLAC (fast Lagrangian analysis of } \\
\text { continua) computer program }\end{array}$ & $\begin{array}{l}\text { Kodikara et al. } \\
{[81]}\end{array}$ & Behavior of curling during desiccation \\
\hline & Finite element method & $\begin{array}{c}\text { Pouya et al. } \\
{[82]}\end{array}$ & Crack propagation in an unsaturated porous body \\
\hline & SPLASH conditions & $\begin{array}{l}\text { Malésys et al. } \\
{[83]}\end{array}$ & $\begin{array}{c}\text { Prediction of the formation and propagation of crack } \\
\text { networks }\end{array}$ \\
\hline & 3D discrete element modeling & $\begin{array}{l}\text { Sima et al. } \\
{[80]}\end{array}$ & $\begin{array}{l}\text { Some of the factors such as the sample thickness, the soil-base } \\
\text { interface, micromechanical parameters, and the soil-water } \\
\text { characteristics were analyzed in the DEM model }\end{array}$ \\
\hline & $\begin{array}{l}\text { Solid finite elements method: } \\
\text { mesh fragmentation technique }\end{array}$ & $\begin{array}{l}\text { Sánchez et al. } \\
\quad[76]\end{array}$ & $3 \mathrm{D}$ crack patterns and cracking behaviors \\
\hline & $\begin{array}{l}\text { Distinct lattice spring model (DLSM) } \\
\text { with a two-phase bond model }\end{array}$ & Gui et al. [40] & $\begin{array}{c}\text { Significant factors, such as soil particle size, heterogeneity, and } \\
\text { boundary conditions. }\end{array}$ \\
\hline \multirow{2}{*}{$\begin{array}{l}\text { Tensile stress } \\
\text { failure approaches }\end{array}$} & Discrete element approach & $\begin{array}{l}\text { Péron et al. } \\
{[39]}\end{array}$ & $\begin{array}{l}\text { Prediction of the time of the occurrence of cracking, as well as } \\
\text { the crack pattern }\end{array}$ \\
\hline & Cohesive crack method & $\begin{array}{l}\text { Amarasiri } \\
\text { et al. [84] }\end{array}$ & $\begin{array}{l}\text { Field desiccation test: crack patterns obtained with time were } \\
\text { monitored and documented }\end{array}$ \\
\hline \multirow{4}{*}{$\begin{array}{l}\text { Fracture } \\
\text { mechanics } \\
\text { approaches }\end{array}$} & $\begin{array}{c}\text { Fracture mechanics } \\
\text { Universal distinct element code } \\
\text { (UDEC) }\end{array}$ & $\begin{array}{l}\text { Amarasiri } \\
\text { et al. [85] }\end{array}$ & $\begin{array}{l}\text { Mode I cracking is modeled and fracture properties of the } \\
\text { propagating crack are gathered }\end{array}$ \\
\hline & $\begin{array}{l}\text { Particle discretization scheme Finite } \\
\text { element method }\end{array}$ & $\begin{array}{l}\text { Hirobe et al. } \\
{[78]}\end{array}$ & Pattern formation, seamless deformation/fracture analysis \\
\hline & Cohesive fracture method & Vo et al. [86] & $\begin{array}{l}\text { Reproduction of the behaviors observed in the experiment } \\
\text { (shrinkage related to drying, crack development). }\end{array}$ \\
\hline & $\begin{array}{l}\text { Hydromechanical model using } \\
\text { fracture mechanics }\end{array}$ & $\begin{array}{l}\text { Levatti et al. } \\
\text { [87] }\end{array}$ & Cracking process in clayey soils \\
\hline
\end{tabular}

this model, the damage-elastic behavior with cohesive fracture was analyzed. The results emphasize the evolution of the stress, strains, and soil-water characteristics at different locations in the soil specimen during drying. Other modelings such as extend distinct lattice spring model (DLSM) can propose a two-phase bond model that can model the cracking process related to desiccation. With this approach, the suction can be represented by the water bond, while the mechanical contact between soil particles is accounted to be the spring bond. Moreover, with this DLSM approach, heterogeneity of soils is also considered by proposing a stochastic distribution of suction values [40].

As an alternative, DEM is an efficient and appropriate approach considering its capability of capturing the discrete nature of soil grains. The "grains" are considered to be independent from the others with DEM method. Thus, each grain is unique and has its own mechanical behavior. The microscopic scale behavior of soils can be reflected by the grain interaction laws. There are various approaches based on discrete elements. Considering cohesive bond among grains, the DEM is paid more attention in the research of cracks related to desiccation [39, 80, 90, 91]. The hybrid continuum-discrete element approach can be used to simulate the shrinkage and cracking process of soils during drying. A mix-mode cohesive fracture model that considers tension, compression, and shear is used in this method. This fracture model also uses elastic and inelastic displacement and strains, respectively. In order to control the fracture behavior, the norms of the effective inelastic displacement and strains are determined. The clay particles gathering in the form of elementary small structures are called aggregates, which are usually simplified as spherical grains or other geometries in DEM (see Figure 9) [80]. The cohesion in the clay during drying is then obtained by increasing the 


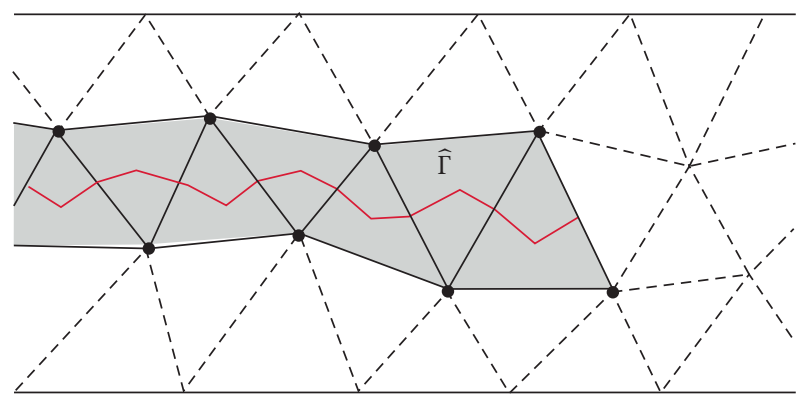

FIGURE 8: Crack model in PDS-FEM for deformation and fracture of a deformable body. Geometry for two-dimensional setting is shown for the sake of simplicity. The blunt crack is illustrated as the area in gray [78].

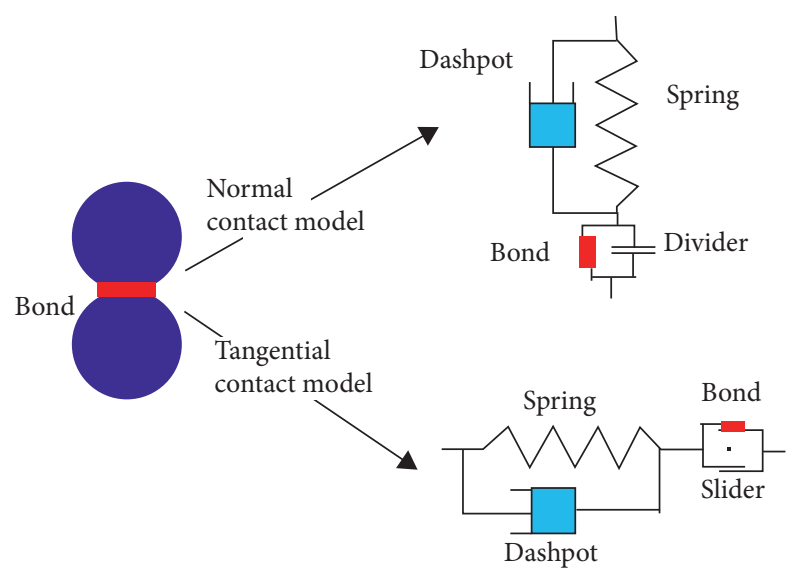

FIgURE 9: Contact models of bonded grains used in the DEM analyses [92].

cohesive force between the elements of the simulated aggregates. During desiccation, the tensile strength and the contact stiffness of the aggregates become larger with increasing suction. The initiation of crack agrees with the irreversible breaking of a cohesive bond, which is larger than tensile strength of soils. The factors such as the soil sample dimensions and the interface between soil and shrinkage parameters during desiccation can also be investigated by simulations.

Generally, the initiation of failure and the propagation of cracks in soils can be provided by DEM method. Thus, the numerical methods can be considered to be an efficient and realistic technique to interpret cracks in clays related to desiccation. They can overcome most of the difficulties in the modeling with FEM method.

\section{Summaries and Conclusions}

The cracking behavior and mechanisms in clayey soils related to desiccation have been paid great attention from numerical researchers during the past several decades. The discussions and contributions on desiccation cracking behavior and mechanisms from the literature are summarized in this paper under two aspects, that is, experiments and mechanisms and numerical methods. This review leads to the following conclusions:
(1) From the experimental review: (a) In nature, orthogonal and nonorthogonal patterns can be observed in desiccation cracking. (b) It is necessary to understand the tensile strength and its relation to water content and degree of saturation during desiccation process of a soil.

(2) Based on soil-mechanical approach: (a) Cracking behavior contains three typical modes: opening mode, sliding mode, and tearing mode, which are the mechanical results. (b) Fracture mechanics is one of the main tools to study the destruction of soil cracking.

(3) From the numerical aspect of view, numerical methods of FEM and DEM are approaches that can overcome the shortcoming of laboratory experimentations. Compared with FEM, DEM can be seen as a more efficient and realistic tool to apply to the study of interpreting cracking mechanisms.

(4) Although cracks in clays have been widely studied by many investigators, there are still some aspects that need more attentions: (a) The quantitative relationship between the cracking parameters and the macroscopic engineering properties are significant. The stability and mechanical properties of geological engineering applications with or without cracks are very different. Thus, for clays with cracks, it is necessary to focus on the influence of cracks in order to make precise evaluations in engineering practice. However, the current research on cracks is mainly limited to the quantitative description of geometric parameters and seldom establishes a quantitative relationship between cracking parameters and macroengineering property. (b) Research on the microstructure of clays and the coupling between the quantitative parameters of the microstructure and the micromechanical model should be paid more attention. The study of microstructure has always been an important research topic. It is also an important method to essentially determine the macroscopic properties of clays. However, the quantitative analysis of microstructure is still at a relatively hard stage. The results obtained are subjected to the sample preparation process, which cause many uncertainties. More importantly, these quantitative results cannot reflect the dynamic evolution process of the engineering properties of clays. Therefore, how to further improve the efficiency on microscopic quantitative parameters is the focus of future research. In addition, how to establish a micromechanical model of clays based on the quantitative parameters of the microstructure and couple it with the corresponding micromechanical model to achieve a relation between the two will be a challenging topic in the future. (c) Response characteristics of engineering properties of clays under multifield coupling is a promising topic. The engineering properties of clays are influenced by the coupling of various factors such as soil structure, 
geological conditions, and environmental climate conditions, especially when some clays are used as special geomaterials in some projects; their deformation and mechanical properties are affected by multifield coupling, such as heat, water, force, and even chemistry. Therefore, identification of the engineering response characteristics of clays under the multifield coupling is significant.

\section{Data Availability}

The data used to support the findings of this study are included within the article.

\section{Conflicts of Interest}

The authors declare that they have no conflicts of interest.

\section{Acknowledgments}

This work was supported by the National Key Research and Development Program of China (no. 2018YFC1504700), the National Natural Science Foundation of China funded project (no. 41790441), and China Postdoctoral Science Foundation (Project no. 2017M623180).

\section{References}

[1] R. Baker, "Tensile strength, tension cracks, and stability of slopes," Soils Found, vol. 21, no. 2, pp. 1-17, 1981.

[2] F. H. Lee, K. W. Lo, and S. L. Lee, "Tension crack development in soils," Journal of Geotechnical Engineering, vol. 114, no. 8, pp. 915-929, 1988.

[3] V. Silvestri, G. Sarkis, N. Bekkouche, and M. Soulié, "Evapotranspiration, trees and damage to foundations in sensitive clays," in Proceedings of the Canadian Geotechnical Conference, vol. II, pp. 533-538, Toronto, Ontorio, 1992.

[4] Y. Y. Tay, D. I. Stewart, and T. W. Cousens, "Shrinkage and desiccation cracking in bentonite-sand landfill liners," Engineering Geology, vol. 60, no. 1-4, pp. 263-274, 2001.

[5] J. H. Li and L. M. Zhang, "Study of desiccation crack initiation and development at ground surface," Engineering Geology, vol. 123, no. 4, pp. 347-358, 2011.

[6] C.-S. Tang, B. Shi, C. Liu, W.-B. Suo, and L. Gao, "Experimental characterization of shrinkage and desiccation cracking in thin clay layer," Applied Clay Science, vol. 52, no. 1-2, pp. 69-77, 2011.

[7] D. Y. Wang, C. S. Tang, B. Shi, and J. Li, "Studying the effect of drying on soil hydromechanical properties using micropenetration method," Environmental Earth Sciences, vol. 75, no. 12, pp. 1-13, 2016.

[8] E. M. Kindle, "Some factors affecting the development of Mud-Cracks," The Journal of Geology, vol. 25, no. 2, pp. 135-144, 1917.

[9] C. R. Longwell, "Three common types of desert mud cracks," American Journal of Science, vol. s5-15, no. 86, pp. 136-145, 1928.

[10] R. Willden and D. R. Mabey, "Giant desiccation fissures on the black rock and smoke creek deserts, Nevada," Science, vol. 133, no. 3461, pp. 1359-1360, 1961.

[11] J. R. L. Allen, "On the curl of desiccation polygons," Sedimentary Geology, vol. 46, no. 1-2, pp. 23-31, 1986.
[12] R. Ayad, J.-M. Konrad, and M. Soulié, "Desiccation of a sensitive clay: Application of the model CRACK," Canadian Geotechnical Journal, vol. 34, no. 6, pp. 943-951, 1997.

[13] K. Pasricha, U. Wad, R. Pasricha, and S. Ogale, "Parametric dependence studies on cracking of clay," Physica A: Statistical Mechanics and its Applications, vol. 388, no. 8, pp. 1352-1358, 2009.

[14] L.-L. Wang, C.-S. Tang, B. Shi, Y.-J. Cui, G.-Q. Zhang, and I. Hilary, "Nucleation and propagation mechanisms of soil desiccation cracks," Engineering Geology, vol. 238, pp. 27-35, 2018.

[15] P. H. Morris, J. Graham, and D. J. Williams, "Cracking in drying soils," Canadian Geotechnical Journal, vol. 29, no. 2, pp. 262-277, 1992.

[16] D. F. Kong, Properties of Fissured Clay, China Map Press, Beijing, China, 1st ed. edition, 1994.

[17] J.-M. Konrad and R. Ayad, "Desiccation of a sensitive clay: Field experimental observations," Canadian Geotechnical Journal, vol. 34, no. 6, pp. 929-942, 1997.

[18] J. Kodikara, P. Rajeev, and N. J. Rhoden, "Determination of thermal diffusivity of soil using infrared thermal imaging," Canadian Geotechnical Journal, vol. 48, no. 8, pp. 1295-1302, 2011.

[19] A. Corte and A. Higashi, "Experimental research on desiccation cracks in soils, research, U.S. army snow ice and permafrost research establishment," Report No. 66, Corps of Engineers, Wilmette, IL, USA, 1960.

[20] J. Lau, "Desiccation cracking of soils," M.S. thesis, University of Saskatchewan, Saskatoon, Canada, 1987.

[21] H. Péron, "Desiccation cracking of soils," Ph. D. thesis, Ecole Polytechnique Fédérale de Lausanne, Lausanne, Switzerland, 2008.

[22] C.-S. Tang, B. Shi, Y.-J. Cui, C. Liu, and K. Gu, "Desiccation cracking behavior of polypropylene fiber-reinforced clayey soil," Canadian Geotechnical Journal, vol. 49, no. 9, pp. 1088-1101, 2012.

[23] C.-S. Tang, D.-Y. Wang, C. Zhu, Q.-Y. Zhou, S.-K. Xu, and B. Shi, "Characterizing drying-induced clayey soil desiccation cracking process using electrical resistivity method," Applied Clay Science, vol. 152, pp. 101-112, 2018.

[24] J. H. Li, L. Li, R. Chen, and D. Q. Li, "Cracking and vertical preferential flow through landfill clay liners," Engineering Geology, vol. 206, pp. 33-41, 2016.

[25] X. Wei, M. Hattab, P. Bompard, and J.-M. Fleureau, "Highlighting some mechanisms of crack formation and propagation in clays on drying path," Géotechnique, vol. 66, no. 4, pp. 287-300, 2016.

[26] Y. Zhang, W. M. Ye, Y. G. Chen, and B. Ye, "Desiccation of nacl-contaminated soil of earthen heritages in the site of Yar city, northwest China," Applied Clay Science, vol. 124-125, pp. 1-10, 2017.

[27] J. H. Li, Z. Lu, L. B. Guo, and L. M. Zhang, "Experimental study on soil-water characteristic curve for silty clay with desiccation cracks," Engineering Geology, vol. 218, pp. 70-76, 2017.

[28] G. Avila, "Study of shrinkage and cracking of clays - application to clay in Bogota," Ph. D. thesis, Polytechnic University of Catalunya, Barcelona, Spain, 2004.

[29] C.-S. Tang, Y.-J. Cui, A.-M. Tang, and B. Shi, "Experiment evidence on the temperature dependence of desiccation cracking behavior of clayey soils," Engineering Geology, vol. 114, no. 3-4, pp. 261-266, 2010. 
[30] X. Wei, "Etude micro-macro de la fissuration des argiles soumises à la dessiccation," Ph. D. thesis, Ecole Centrale Paris, Châtenay-Malabry, France, 2014.

[31] L. Xu and M. R. Coop, "Influence of structure on the behavior of a saturated clayey loess," Canadian Geotechnical Journal, vol. 53, no. 6, pp. 1026-1037, 2016.

[32] H. Tang, Y. Dong, T. Wang, and Y. Dong, "Simulation of strain localization with discrete element-Cosserat continuum finite element two scale method for granular materials," Journal of the Mechanics and Physics of Solids, vol. 122, pp. 450-471, 2019.

[33] A. N. Abu-Hejleh and D. Znidarčić, "Desiccation theory for soft cohesive soils," Journal of Geotechnical Engineering, vol. 121, no. 6, pp. 493-502, 1995.

[34] V. Y. Chertkov, "Modeling the pore structure and shrinkage curve of soil clay matrix," Geoderma, vol. 95, no. 3-4, pp. 215-246, 2000.

[35] V. Y. Chertkov, "Modelling cracking stages of saturated soils as they dry and shrink," European Journal of Soil Science, vol. 53, no. 1, pp. 105-118, 2002.

[36] V. Y. Chertkov and I. Ravina, "Modeling the crack network of swelling clay soils," Soil Science Society of America Journal, vol. 62, no. 5, pp. 1162-1171, 1998.

[37] G. Deng and Z. J. Shen, "Numerical simulation of crack formation process in clays during drying and wetting," Geomechanics and Geoengineering, vol. 1, no. 1, pp. 27-41, 2006.

[38] J.-M. Konrad and R. Ayad, "A idealized framework for the analysis of cohesive soils undergoing desiccation," Canadian Geotechnical Journal, vol. 34, no. 4, pp. 477-488, 1997.

[39] H. Péron, T. Hueckel, L. Laloui, and L. B. Hu, "Fundamentals of desiccation cracking of fine-grained soils: Experimental characterisation and mechanisms identification," Canadian Geotechnical Journal, vol. 46, no. 10, pp. 1177-1201, 2009.

[40] Y. Gui and G.-F. Zhao, "Modelling of laboratory soil desiccation cracking using DLSM with a two-phase bond model," Computers and Geotechnics, vol. 69, pp. 578-587, 2015.

[41] A. Zein El Abedine and G. H. Robinson, "A study on cracking in some vertisols of the Sudan," Geoderma, vol. 5, no. 3, pp. 229-241, 1971.

[42] L. A. Lima and M. E. Grismer, "Soil crack morphology and soil Salinity1," Soil Science, vol. 153, no. 2, pp. 149-153, 1992.

[43] V. Hallaire, "Description of microcrack orientation in a clayey soil using image analysis," in Soil Micromorphology: Studies in Management and Genesis. Developments in Soil Science, A. J. Ringrose-oase and G. S. Humphreys, Eds., vol. 22, pp. 549557, Elsevier, Amsterdam, Netherland, 1994.

[44] C. J. Miller, H. Mi, and N. Yesiller, "Experimental analysis of desiccation crack propagation in clay liners," Journal of the American Water Resources Association, vol. 34, no. 3, pp. 677-686, 1998.

[45] N. Yesiller, C. J. Miller, G. Inci, and K. Yaldo, "Desiccation and cracking behavior of three compacted landfill liner soils," Engineering Geology, vol. 57, no. 1-2, pp. 105-121, 2000.

[46] M. R. Lakshmikantha, P. C. Prat, and A. Ladesma, "An experimental study of cracking mechanisms in drying soils," in Proceedings of the 5th International Conference on Environmental Geotechnics, pp. 533-540, Oxford, London, 2006.

[47] J. A. Cordero, G. Useche, P. C. Prat, A. Ledesma, and J. C. Santamarina, "Soil desiccation cracks as a suctioncontraction process," Géotechnique Letters, vol. 7, no. 4, pp. 272-278, 2017.
[48] A. Groisman and E. Kaplan, "An experimental study of cracking induced by desiccation," Europhysics Letters (EPL), vol. 25, no. 6, pp. 415-420, 1994.

[49] A. Toramaru and T. Matsumoto, "Columnar joint morphology and cooling rate: A starch-water mixture experiment," Journal of Geophysical Research: Solid Earth, vol. 109, no. B2, pp. 1-10, 2004.

[50] S. Costa, J. Kodikara, and B. Shannon, "Salient factors controlling desiccation cracking of clay in laboratory experiments," Géotechnique, vol. 63, no. 1, pp. 18-29, 2013.

[51] H. Nahlawi and J. K. Kodikara, "Laboratory experiments on desiccation cracking of thin soil layers," Geotechnical and Geological Engineering, vol. 24, no. 6, pp. 1641-1664, 2006.

[52] L. K. Philip, H. Shimell, P. J. Hewitt, and H. T. Ellard, "A fieldbased test cell examining clay desiccation in landfill liners," Quarterly Journal of Engineering Geology and Hydrogeology, vol. 35, no. 4, pp. 345-354, 2002.

[53] Z. P. Bazant and F. H. Wittmann, Creep and Shrinkage in Concrete Structures, Wiley, New York, NY, USA, 1982.

[54] J. Kodikara, S. L. Barbour, and D. G. Fredlund, "Changes in clay structure and behavior due to wetting and drying," in Proceedings of the 8th Australian-New Zealand Conference on Geomechanics, pp. 179-186, Hobart, Australia, 1999.

[55] R. Auvray, S. Rosin-Paumier, A. Abdallah, and F. Masrouri, "Quantification of soft soil cracking during suction cycles by image processing," European Journal of Environmental and Civil Engineering, vol. 18, no. 1, pp. 11-32, 2014.

[56] X. Peng, R. Horn, S. Peth, and A. Smucker, "Quantification of soil shrinkage in $2 \mathrm{D}$ by digital image processing of soil surface," Soil and Tillage Research, vol. 91, no. 1-2, pp. 173-180, 2006.

[57] A. W. Bishop and V. K. Garga, "Drained tension tests on London clay," Géotechnique, vol. 19, no. 2, pp. 309-313, 1969.

[58] A. V. Krishnayya, Z. Eisenstein, and N. R. Morgenstern, "Behavior of compacted soil in tension," Journal of the Geotechnical Engineering, vol. 100, no. 9, pp. 1051-1061, 1974.

[59] A. Ajaz and R. H. G. Parry, "Stress-strain behaviour of two compacted clays in tension and compression," Géotechnique, vol. 25, no. 3, pp. 495-512, 1975.

[60] M. V. Villar, R. Gomez, and A. Lloret, "Experimental investigation into temperature effect on hydro-mechanical behaviours of bentonite," Journal of Rock Mechanics and Geotechnical Engineering, vol. 2, no. 1, pp. 71-78, 2010.

[61] K. V. G. K. Gokhale and M. Anandakrishnan, "Role of active clay in the shrinkage behaviour in multicomponent clay-sand systems," Soils and Foundations, vol. 10, no. 3, pp. 92-94, 1970.

[62] A. Sridharan and R. G. Venkatappa, "Effective stress theory of shrinkage phenomena," Canadian Geotechnical Journal, vol. 8, no. 4, pp. 505-513, 1971.

[63] J. H. Kleppe and R. E. Olson, "Desiccation cracking of soil barriers," ASTM Special Technical Publication, West Conshohocken, PA, USA, 1985.

[64] N. M. Newmark, "Failure hypotheses for soils," in Proceedings of the Resources Conference on Shear Strength of Cohesive Soils, ASCE, Boulder, CO, USA, June 1960.

[65] W. F. Brace, "An extension of the Griffith theory of fracture to rocks," Journal of Geophysical Research, vol. 65, no. 10, pp. 3477-3480, 1960.

[66] S. Frydman, "Triaxial and tensile strength tests on stabilized soil," in Proceedings of the 3rd Asian Regional Conference Soil Mechanics and Foundation Engineering, vol. 1, pp. 269-271, Haifa, Israel, 1967. 
[67] I. K. Lee and O. G. Ingles, "Soil mechanics selected topics" in Strength and Deformation of Soils and Rocks, I. K. Lee, Ed., pp. 195-295, Butterworths, London, UK, 1968.

[68] H. Y. Fang and W. F. Chen, "New method for determination of tensile strength of soils," Highway Research Record, vol. 345, pp. 62-68, 1971.

[69] H. Y. Fang and W. F. Chen, "Further study of double punch test for tensile strength of soils," in Proceedings of the $3 \mathrm{rd}$ Southeast Asian Conference Soil Mechanics and Foundation Engineering, pp. 211-215, Hong Kong, China, 1972.

[70] A. A. Griffith, "The phenomena of rupture and flow in solids," Transaction Royal Society of London. Series A, vol. 221, pp. 163-198, 1921.

[71] A. A. Griffith, "The theory of rupture," in Proceedings of the Fifth International Congress for Applied Mechanics, pp. 55-63, Delft Netherlands, April 1924.

[72] O. C. Zienkiewicz, The Finite Element Method, McGraw-Hill, New York, NY, USA, 3rd edition, 1977.

[73] Z. Shen and G. Deng, "Numerical simulation of crack evolution in clay during drying and wetting cycle," Rock and Soil Mechanics, vol. 25, pp. 1-7, 2004.

[74] S. Youshida and K. Adachi, "Numerical analysis of crack generation in saturated deformable soil under row-planted vegetation," Geoderma, vol. 120, no. 1-2, pp. 63-74, 2004.

[75] H. Péron, L. Hu, L. Laloui, and T. Hueckel, "Numerical and experimental investigation of desiccation of soil," in Proceedings of the Asian Conference on Unsaturated Soils, vol. 3, pp. 3-8, Nanjing, China, October 2007.

[76] M. Sanchez, A. Atique, S. Kim, E. Romero, and M. Zielinski, "Exploring desiccation cracks in soils using a 2D profile laser device," Acta Geotechnica, vol. 8, no. 6, pp. 583-596, 2013.

[77] H. Trabelsi, M. Jamei, H. Zenzri, and S. Olivella, "Crack patterns in clayey soils: Experiments and modeling," International Journal for Numerical and Analytical Methods in Geomechanics, vol. 36, no. 11, pp. 1410-1433, 2012.

[78] S. Hirobe and K. Oguni, "Modeling and numerical investigations for hierarchical pattern formation in desiccation cracking," Physica D: Nonlinear Phenomena, vol. 359, pp. 29-38, 2017.

[79] A. Kharaghani, T. Metzger, and E. Tsotsas, "An irregular pore network model for convective drying and resulting damage of particle aggregates," Chemical Engineering Science, vol. 75, pp. 267-278, 2012.

[80] J. Sima, M. Jiang, and C. Zhou, "Numerical simulation of desiccation cracking in a thin clay layer using $3 \mathrm{D}$ discrete element modeling," Computers and Geotechnics, vol. 56, pp. 168-180, 2014.

[81] J. K. Kodikara, H. Nahlawi, and A. Bouazza, "Modelling of curling in desiccating clay," Canadian Geotechnical Journal, vol. 41, no. 3, pp. 560-566, 2004.

[82] A. Pouya, "A finite element method for modeling coupled flow and deformation in porous fractured media," International Journal for Numerical and Analytical Methods in Geomechanics, vol. 39, no. 16, pp. 1836-1852, 2015.

[83] N. Malésys, L. Vincent, and F. Hild, "A probabilistic model to predict the formation and propagation of crack networks in thermal fatigue," International Journal of Fatigue, vol. 31, no. 3, pp. 565-574, 2009.

[84] A. L. Amarasiri and J. K. Kodikara, "Numerical modelling of a field desiccation test," Géotechnique, vol. 63, no. 11, pp. 983-986, 2013.

[85] A. L. Amarasiri and J. K. Kodikara, "Numerical modeling of desiccation cracking using the cohesive crack method,"
International Journal of Geomechanics, vol. 13, no. 3, pp. 213-221, 2013.

[86] T. D. Vo, A. Pouya, S. Hemmati, and A. M. Tang, "Numerical modelling of desiccation cracking of clayey soil using a cohesive fracture method," Computers and Geotechnics, vol. 85, pp. 15-27, 2017.

[87] H. U. Levatti, P. C. Prat, and A. Ledesma, "Numerical and experimental study of initiation and propagation of desiccation cracks in clayey soils," Computers and Geotechnics, vol. 105, pp. 155-167, 2019.

[88] R. Rodríguez, M. Sánchez, A. Ledesma, and A. Lloret, "Experimental and numerical analysis of desiccation of a mining waste," Canadian Geotechnical Journal, vol. 44, no. 6, pp. 644-658, 2007.

[89] O. Coussy and S. Brisard, "Prediction of drying shrinkage beyond the pore isodeformation assumption," Journal of Mechanics of Materials and Structures, vol. 4, no. 2, pp. 263-279, 2009.

[90] A. Amarasiri, J. Kodikara, and S. Costa, "Numerical modelling of desiccation cracking," International Journal for Numerical and Analytical Methods in Geomechanics, vol. 48, pp. 336340, 2010.

[91] R. A. Stirling, "Multiphase modelling of desiccation cracking in compacted soil," Ph. D thesis, Newcastle University, Newcastle, Tyne, England, 2014.

[92] M. Jiang, S. Leroueil, and J.-M. Konrad, "Yielding of microstructured geomaterial by distinct element method analysis," Journal of Engineering Mechanics, vol. 131, no. 11, pp. 1209-1213, 2005. 